\title{
A rare testicular vein anatomical variant contributes to right-sided varicocoele formation and leads to the diagnosis of renal cell carcinoma
}

\author{
James William Ryan, Gavin Sugrue, Sandra Graham, Carmel Cronin
}

Department of Radiology, Mater Misericordiae University Hospital, Dublin, Ireland

\section{Correspondence to} Dr James William Ryan, jamesryannchd@gmail.com

Accepted 2 June 2017
CrossMark

To cite: Ryan JW, Sugrue G, Graham S, et al. BMJ Case Rep Published Online First: [please include Day Month Year]. doi:10.1136/bcr-2017 219519

\section{DESCRIPTION}

A man in his 60 s presented for a testicular ultrasound due to asymptomatic scrotal swelling. Ultrasound showed a right-sided varicocoele (figure 1). A varicocoele is an abnormal dilatation of the pampiniform venous plexus in the scrotum. A renal ultrasound demonstrated a heterogeneous mass arising from the right kidney (figure 2). Histology subsequently revealed a renal cell carcinoma. CT identified duplication of the right testicular vein (figure 3 ). The first emptied into the inferior venacava (IVC) as expected. The second had a tortuous course arcing over the upper pole of the right kidney and emptying into the right renal vein (figure 4). Tumour extension into the

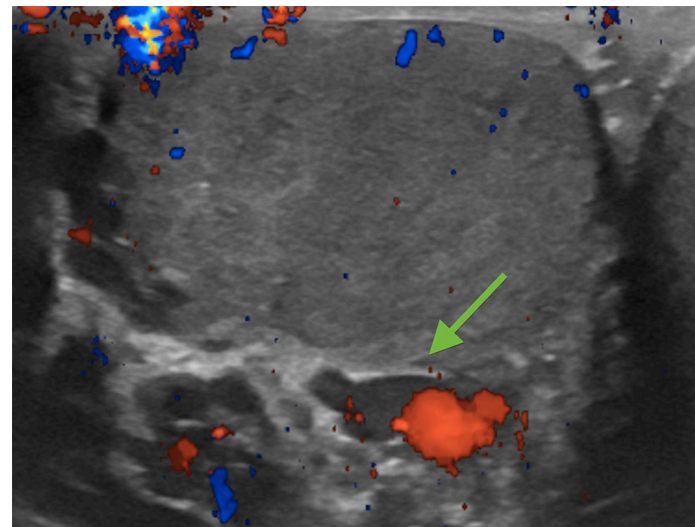

Figure 1 Doppler ultrasound of the right testicle; the green arrow points to a dilated vein in the pampiniform plexus. There is sustained flow reversal in this vessel during Valsalva.

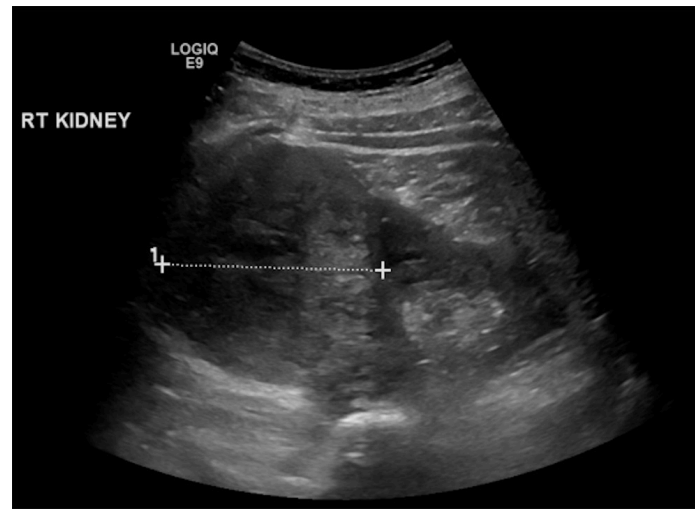

Figure 2 Ultrasound of the right kidney; there is a large mass lesion arising from the right kidney. right renal vein obstructed inflow from this accessory testicular vein and contributed to varicocoele formation (figure 5). Less than 1\% of males have duplicate right testicular vein anatomy. ${ }^{1}$

Ninety-three per cent of varicocoeles occur on the left, the majority of which have a non-pathological aetiology. ${ }^{2}$ Differences in testicular vein length,

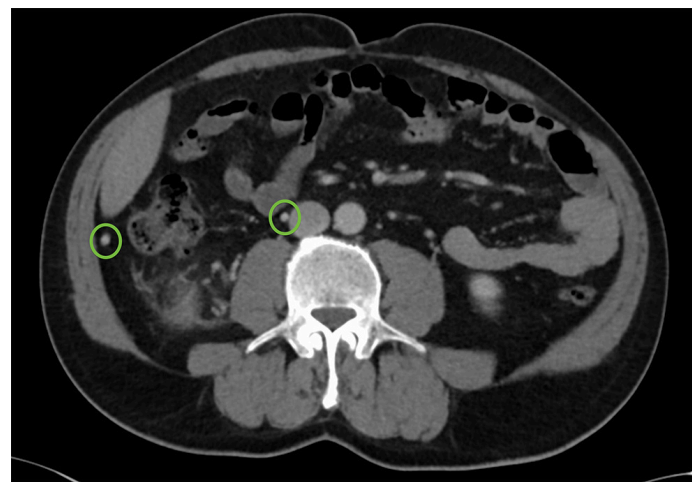

Figure 3 Contrast-enhanced CT of the abdomen portal venous phase. The right testicular vein is circled medially, the accessory right testicular vein laterally.

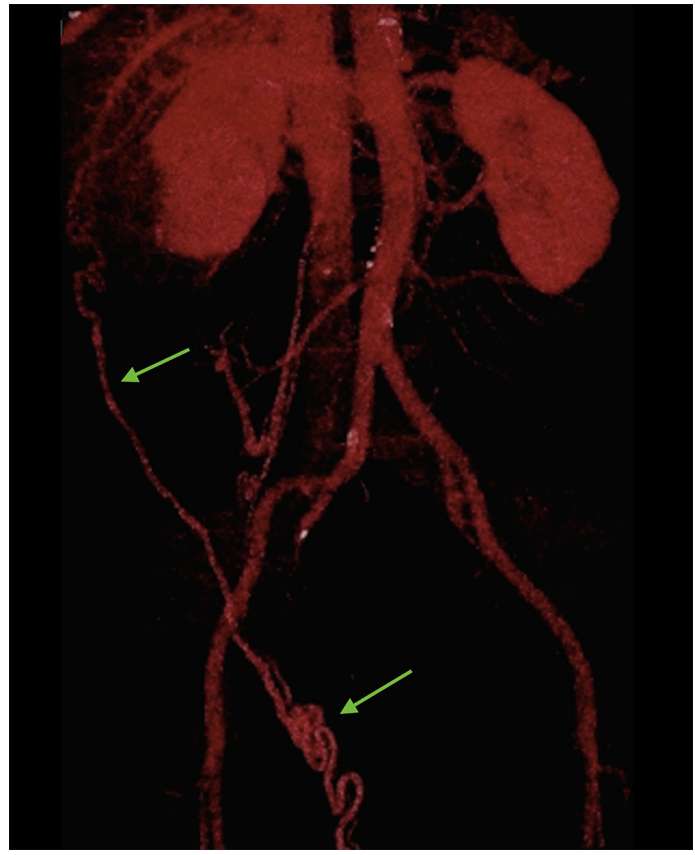

Figure 4 Three-dimensional reconstruction of the accessory right renal vein. 


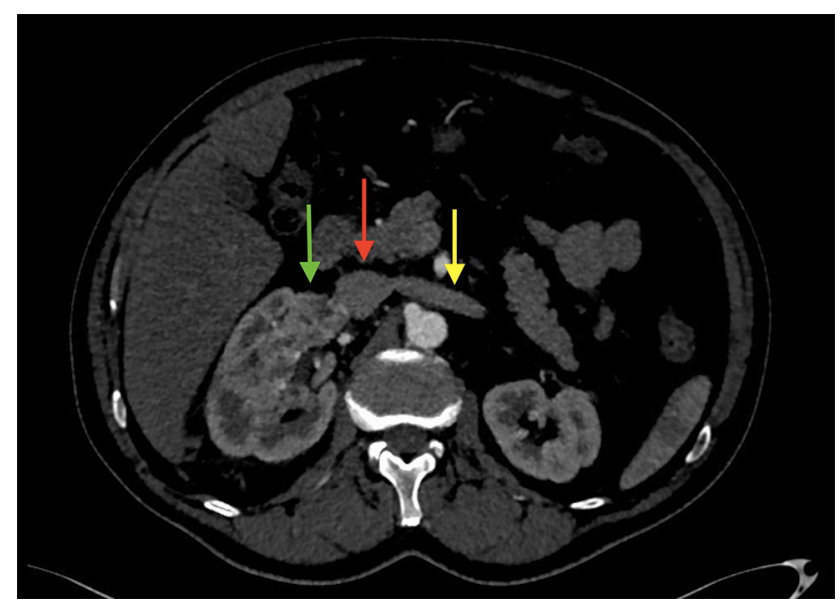

Figure 5 Contrast-enhanced CT of the abdomen arterial phase. The green arrow points to an enhancing renal tumour extending to involve the right renal vein. The red arrow points to the inferior vena cava, which is not involved. The yellow arrow points to the normal left renal vein.

drainage and angle of insertion contribute to the left-sided predominance. ${ }^{3}$ The prevalence of varicocoele increases with age at a rate of approximately $10 \%$ per decade of life. Up to $53 \%$ of males in their 60 s will have a varicocoele. ${ }^{4}$ Pathological causes of varicocoele include extrinsic compression by a retroperitoneal mass and venous thrombosis. ${ }^{2}$ Varicocoeles may present with pain, scrotal swelling and can be diagnosed on clinical examination. ${ }^{1}$ Subclinical varicocoeles require imaging for diagnosis. ${ }^{5}$ Doppler ultrasound is the imaging modality of choice. Factors such as vessel diameter and flow reversal on Valsalva can be used to diagnose and grade varicocoeles.
Learning points

- Varicocoele prevalence increases with age at a rate of approximately $10 \%$ per decade, ${ }^{4}$ and $93 \%$ occur on the left. ${ }^{2}$

- Right-sided varicocoele in an adult should always prompt further imaging to rule out pathological causes.

- Doppler ultrasound is the imaging modality of choice in the diagnosis and grading of subclinical varicocoeles as it has high diagnostic accuracy and is non-invasive. ${ }^{5}$

Contributors JWR is the first author. GS acquired images. SG provided reconstructed three-dimensional images. CC is the senior author.

Competing interests None declared.

Patient consent Detail has been removed from this case description/these case descriptions to ensure anonymity. The editors and reviewers have seen the detailed information available and are satisfied that the information backs up the case the authors are making.

Provenance and peer review Not commissioned; externally peer reviewed.

(c) BMJ Publishing Group Ltd (unless otherwise stated in the text of the article) 2017. All rights reserved. No commercial use is permitted unless otherwise expressly granted.

\section{REFERENCES}

1 Kara T, Younes M, Erol B, et al. Evaluation of testicular vein anatomy with multidetector computed tomography. Surg Radiol Anat 2012:34:341-5.

2 El-Saeity NS, Sidhu PS. "Scrotal varicocele, exclude a renal tumour". Is this evidence based? Clin Radio/ 2006;61:593-9.

3 Woodward PJ, Schwab CM, Sesterhenn IA. From the archives of the AFIP: extratesticular scrotal masses: radiologic-pathologic correlation. Radiographics 2003:23:215-40-40.

4 Alsaikhan B, Alrabeeah K, Delouya G, et al. Epidemiology of varicocele. Asian J Androl 2016;18:179-81.

5 Chiou RK, Anderson JC, Wobig RK, et al. Color Doppler ultrasound criteria to diagnose varicoceles: correlation of a new scoring system with physical examination. Urology 1997;50:953-6.

Copyright 2017 BMJ Publishing Group. All rights reserved. For permission to reuse any of this content visit

http://group.bmj.com/group/rights-licensing/permissions.

BMJ Case Report Fellows may re-use this article for personal use and teaching without any further permission.

Become a Fellow of BMJ Case Reports today and you can:

- Submit as many cases as you like

- Enjoy fast sympathetic peer review and rapid publication of accepted articles

- Access all the published articles

- Re-use any of the published material for personal use and teaching without further permission

For information on Institutional Fellowships contact consortiasales@bmjgroup.com

Visit casereports.bmj.com for more articles like this and to become a Fellow 